\title{
Funkcjonowanie zakładów przemysłowych XXI wieku na przykładzie Swedwood Poland i Volkswagen Motor Polska Sp. z o.0. Analiza dojazdów do pracy
}

\section{WPROWADZENIE}

Intensywna kolonizacja przemysłu polskiego przez korporacje międzynarodowe, która rozpoczęła się w ostatniej dekadzie XX wieku, doprowadziła do zmian w jego strukturze przestrzennej zarówno na poziomie całego kraju, jak również w układach lokalnych i regionalnych. Nowe inwestycje zagraniczne wielkich firm międzynarodowych poprzez zakup prywatyzowanych zakładów lub typu greenfield spowodowały przerwanie starych układów kooperacyjnych czy zaopatrzeniowych i wykształcenie nowych powiązań przestrzennych między zakładami i ich otoczeniem. Kształtowanie się nowych relacji, szczególnie przestrzennych, jest jednak procesem długofalowym, stąd perspektywa końca pierwszej dekady XXI wieku wydaje się dobrym momentem do podjęcia próby sformułowania pewnych uogólnień. Analiza powiązań przestrzennych zakładów powstałych w wyniku inwestycji zagranicznych powinna właśnie w pierwszym rzędzie dotyczyć dojazdów do pracy. Są one bowiem jednym z najlepszych mierników zasięgu oddziaływania zakładu przemysłowego, ponadto pierwszą i najbardziej podstawową więzią nowego zakładu w nowym otoczeniu i społeczności lokalnej, a w rezultacie mogą wskazywać na stopień jego zakorzenienia (embeddedness) $\mathrm{w}$ regionie.

Celem opracowania jest charakterystyka funkcjonowania dwóch zakładów przemysłowych będących oddziałami koncernów międzynarodowych inwestujących w przemyśle polskim: Swedwood International Ltd. oddział w Chlastawie (w gminie Zbąszynek, województwo lubuskie) i Volkswagen Motor Polska w Polkowicach (województwo dolnośląskie). Sa to dwie inwestycje typu greenfield, uruchomione na przełomie wieków. Jednym z ważnych aspektów ich oddziaływania na otaczający obszar są dojazdy do pracy. Oba zakłady przemysłowe należą do korporacji międzynarodowych (generujących procesy globalizacji) oraz są silnymi podmiotami wpływającymi na strukturę gospodarczą i rynek pracy regionu. 


\section{KORPORACJE MIĘDZYNARODOWE \\ JAKO PRZEDMIOT BADAŃ GEOGRAFII EKONOMICZNEJ}

Korporacje międzynarodowe, ich funkcjonowanie i oddziaływanie stały się przedmiotem badań geografii ekonomicznej w Polsce wraz z początkiem okresu transformacji gospodarczej, a wpływ na to miał również gwałtowny wzrost ich znaczenia w gospodarce globalnej w tym okresie. Korporacje międzynarodowe uznawane są za jeden z najważniejszych podmiotów współczesnej gospodarki światowej generujący procesy globalizacji. Posiadają pewne wyróżniające je wśród innych przedsiębiorstw cechy przestrzenne, takie jak zdolność do ekspansji zagranicznej w postaci przepływu bezpośrednich inwestycji zagranicznych (BIZ) oraz rozproszenie działalności w różnych regionach geograficznych. Ponadto korporacje międzynarodowe wpływają na kształtowanie się struktury gospodarki, w tym także przestrzennej, na różnych poziomach: lokalnym, regionalnym, globalnym. Cechy te sprawiły, że korporacje międzynarodowe stały się przedmiotem badań geografii ekonomicznej, w szczególności geografii przedsiębiorstw - nurtu, który można wydzielić z subdyscypliny geografii przemysłu i w którym szczegółowo przedstawia się lokalizację, oddziaływanie i organizację przestrzenną przedsiębiorstw, w tym również międzynarodowych (por. np. Domański 1997, Tobolska 2004, Śleszyński 2007). W literaturze bardzo różnie definiuje się korporacje międzynarodowe (por. np. Tobolska 2008), ale najczęściej poprzez wyeksponowanie charakterystycznych ich cech, do których zalicza się przede wszystkim funkcjonowanie w skali międzynarodowej oraz specyficzną organizację w formie konglomeratu mniej lub bardziej zcentralizowanych jednostek organizacyjnych. Ponadto termin „korporacje” uwypukla znaczenie względnie trwałych i uregulowanych wewnętrznym prawem powiązań między członkami takiej organizacji. Z kolei to rozproszenie międzynarodowe wewnętrznych elementów takiej organizacji korporacyjnej wskazuje na możliwość poddania ich analizie przestrzennej, np. ze względu na stopień koncentracji ich zasobów lub funkcji. Również organizacja przestrzenna, a przede wszystkim sposób konfiguracji jednostek wewnętrznych korporacji oraz ich koordynacji, stały się podstawowymi kryteriami do identyfikacji różnych postaci (wzorów) internacjonalizacji przedsiębiorstw, opracowanymi na gruncie nauk z zakresu teorii organizacji i zarządzania. Do najbardziej znanych w tym zakresie należy koncepcja z 1986 roku C.A. Bartletta i S. Ghoshala, którzy wyróżniają cztery typy przedsiębiorstw: międzynarodowe, wielonarodowe, globalne i transnarodowe (za Kutschker, Schmid, 2005, Tobolska, 2006a). Odmienna typologia firm międzynarodowych przedstawiona została w koncepcji H. Perlmuttera, który także wyróżnił 4 orientacje internacjonalizacji przedsiębiorstw: etnocentryczne, policentryczne, geocentryczne i regiocentryczne (por. np. Rymarczyk 2004, Kutschker, Schmid 2005, Wdowicka 2005).

Inną przesłanką do analizy zmian w międzynarodowej strukturze przestrzennej działalności korporacji oraz ich integracji i koordynacji jest koncepcja łańcucha wartości dodanej Portera (o modelu Portera m.in. Gorynia 2007, Zorska 1998, Stryjakiewicz 1999). Przedsiębiorstwo w postaci modelu łańcucha wartości dodanej może zostać zdekomponowane, tj. poszczególne funkcje mogą ulec fragmentaryzacji, a jednocześnie delokalizacji do różnych miejsc, regionów czy krajów. Każdy rodzaj działalności przedsiębiorstwa składający się na łańcuch wartości (m.in. logistyka, produkcja, zbyt, finanse, marketing, badania i rozwój) może być oddzielnym, mniej lub bardziej niezależnym ogniwem przedsiębiorstwa (jednostką organizacyjną). Opierając się na porterowskim modelu łańcucha wartości dodanej 
P. Dicken (1998, za Stonehouse G., Hamill J., i in. 2001) przedstawił koncepcję produkcji globalnej jako powiązanych ze sobą funkcji systemu produkcji tworzących sieć relacji. Autor wyróżnił dwa rodzaje powiązań: wewnętrzne (w postaci międzynarodowej sieci powiązań w ramach firmy globalnej) oraz zewnętrzne (czyli sieć powiązań zewnętrznych z różnymi firmami na rynku). Zewnętrzną i wewnętrzną sieć powiązań firmy międzynarodowej wyznacza sposób organizacji transakcji między podmiotami oraz ich koordynacja. Jeżeli łańcuch transakcji jest realizowany wewnątrz firmy, to możemy mówić o internalizacji, a jeżeli każda funkcja realizowana jest przez inną odrębną jednostkę, to wówczas transakcje podlegają eksternalizacji. W oparciu o ten sam mechanizm powiązań transakcyjnych, a także informacyjno-komunikacyjnych Kutschker i Schmid (2005) wyróżniają analogiczne dwa rodzaje struktur sieciowych: (1) intraorganizacyjne i (2) interorganizacyjne (ich przedstawienie modelowe zob. Tobolska, 2006b). Ponadto Dicken wyznaczył cztery typy wewnętrznej strategii produkcyjnej korporacji międzynarodowej, odzwierciedlające sposoby organizacji jednostek wewnętrznych korporacji, m.in. ze względu ich konfigurację geograficzną. Są to: (1) produkcja skoncentrowana globalnie, (2) produkcja w kraju macierzystym, (3) specjalizacja w zakresie produktu dla rynku globalnego lub regionalnego, (4) transnarodowa integracja pionowa.

\section{FUNKCJONOWANIE POLSKICH ODDZIAŁÓW KORPORACJI MIĘDZYNARODOWYCH - CHARAKTERYSTYKA}

\section{Swedwood International Ltd Oddzial Fabryki West w Chlastawie}

Swedwood International Ltd to korporacja składająca się z 36 oddziałów produkcyjnych, takich jak tartaki, fabryki komponentów dla przemysłu meblarskiego oraz fabryki mebli, a jedynym odbiorcą tych wyrobów jest sieć sklepów IKEA. Korporacja jest przykładem ugrupowania jednostek produkcyjnych zintegrowanych pionowo w łańcuchu tworzenia wartości: od pozyskania surowca (tj. drewna z tartaków) do produktu finalnego (tj. mebli) i jego dostaw do odbiorcy, tj. IKEA. Poszczególne oddziały ugrupowania zlokalizowane są w 9 krajach Europy: Szwecji, Niemczech, Polsce, Słowacji, Łotwie, Rumunii, na Węgrzech, Ukrainie i w Rosji (ryc. 1). W trakcie budowy i uruchamiania są fabryki w Portugalii, Stanach Zjednoczonych i Chinach.

W całej korporacji Swedwood w 2007 roku zatrudnionych było ok. 14000 pracowników, z czego 93\% poza Szwecją. Produkcja koncernu jest również realizowana w przeważającej części poza Szwecją, tj. w 86\% swojej wartości (dane z 2007).

Internacjonalizacja tego międzynarodowego przedsiębiorstwa następowała od momentu jego powstania w 1991 roku poprzez inwestycje bezpośrednie zarówno typu greenfield, jak i zakupy istniejących fabryk na terenie krajów goszczących. Kolejne etapy ekspansji zagranicznej Swedwood obejmowały więc budowę nowych fabryk oraz zakupy istniejących już miejscowych fabryk i tartaków, które doinwestowywano i rozbudowywano, np. w 1992 zakupiono fabryki w Zbąszyniu i Babimoście (Polska). W roku 2000 wybudowano nowe obiekty fabryczne we wsi Chlastawa w gminie Zbąszynek, na granicy województwa lubuskiego i wielkopolskiego. Fabryka w Chlastawie to bardzo duży obiekt przemysłowy, składający się z kilku hal produkcyjnych o łącznej powierzchnia $185000 \mathrm{~m}^{2}$. Zatrudnienie w tym olbrzymim zakładzie znajduje obecnie 2079 osób (stan w marcu 2008). 


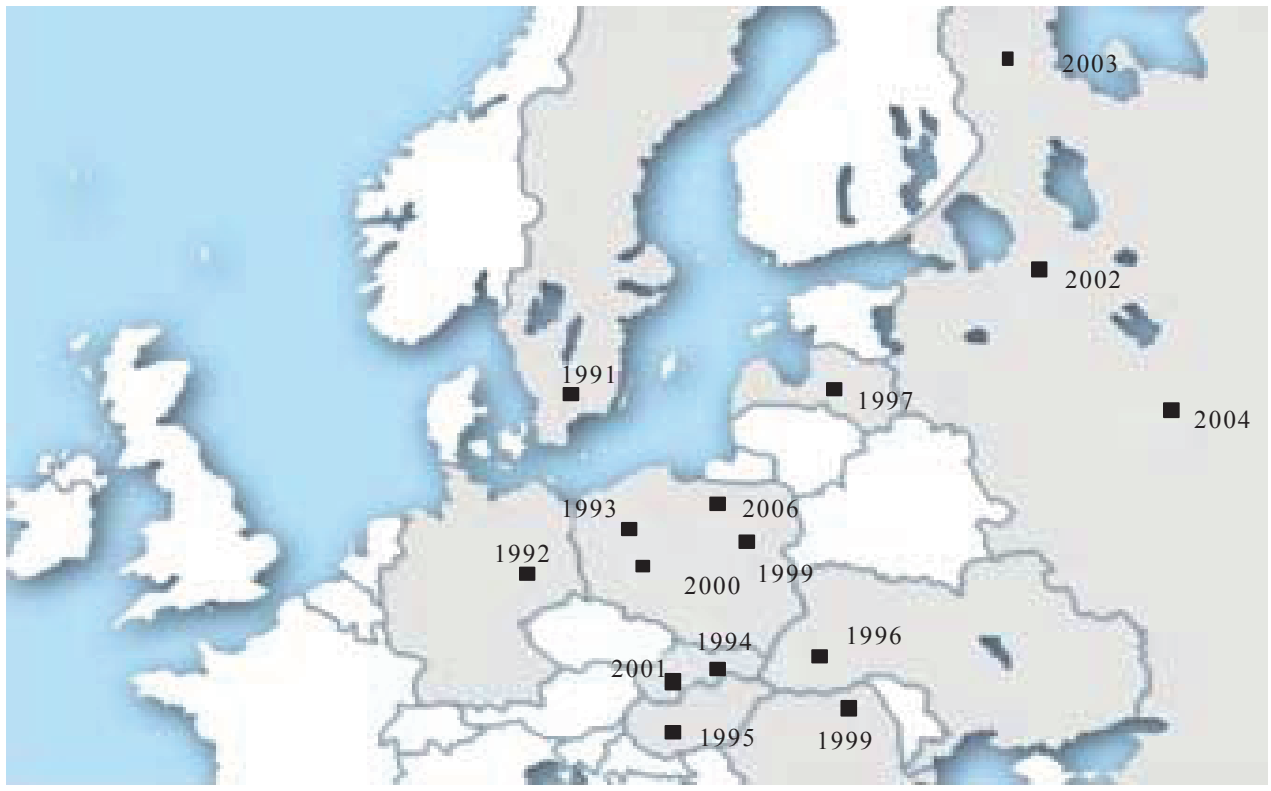

Ryc. 1. Lokalizacja oddziałów i filii Swedwood International Ltd w poszczególnych latach ekspansji zagranicznej

Źródło: opracowanie własne na podst. danych z przedsiębiorstwa

\section{Volkswagen Motor Polska Sp. z o.o.}

W 1998 Rada Nadzorcza spółki Volkswagen AG wybrała lokalizację dla swojej nowej fabryki silników wysokoprężnych w Legnickiej Specjalnej Strefie Ekonomicznej w Polkowicach. W 1999 otwarto fabrykę i uruchomiono produkcję silników dla wszystkich fabryk koncernu VW, zarówno na terenie Niemiec: Emden, Kassel, Hanower, Mozela, a także w Poznaniu, Portugalii (Setubal), Belgii (Bruksela), RPA, Chinach, Meksyku. W Polkowicach produkowane są silniki wysokoprężne dla 17 modeli samochodów, m.in. VW, Seat, Skoda, Audi. Oprócz Polkowic takie same silniki Diesla w koncernie Volkswagen AG produkują zakłady w Salzgitter w Niemczech i Gyor na Węgrzech - są to bezpośredni konkurenci dolnośląskiej fabryki. W fabryce w Polkowicach pracowało w końcu 2007 roku 1184 osoby, a $17 \%$ kadry menedżerskiej stanowili cudzoziemcy.

Produkcja w polkowickiej fabryce VW obejmuje dwa główne działy: obróbkę mechaniczną i montaż i jest prowadzona w oparciu o nowoczesne techniki zarządzania związane $\mathrm{z}$ lean management i outsourcingiem. 


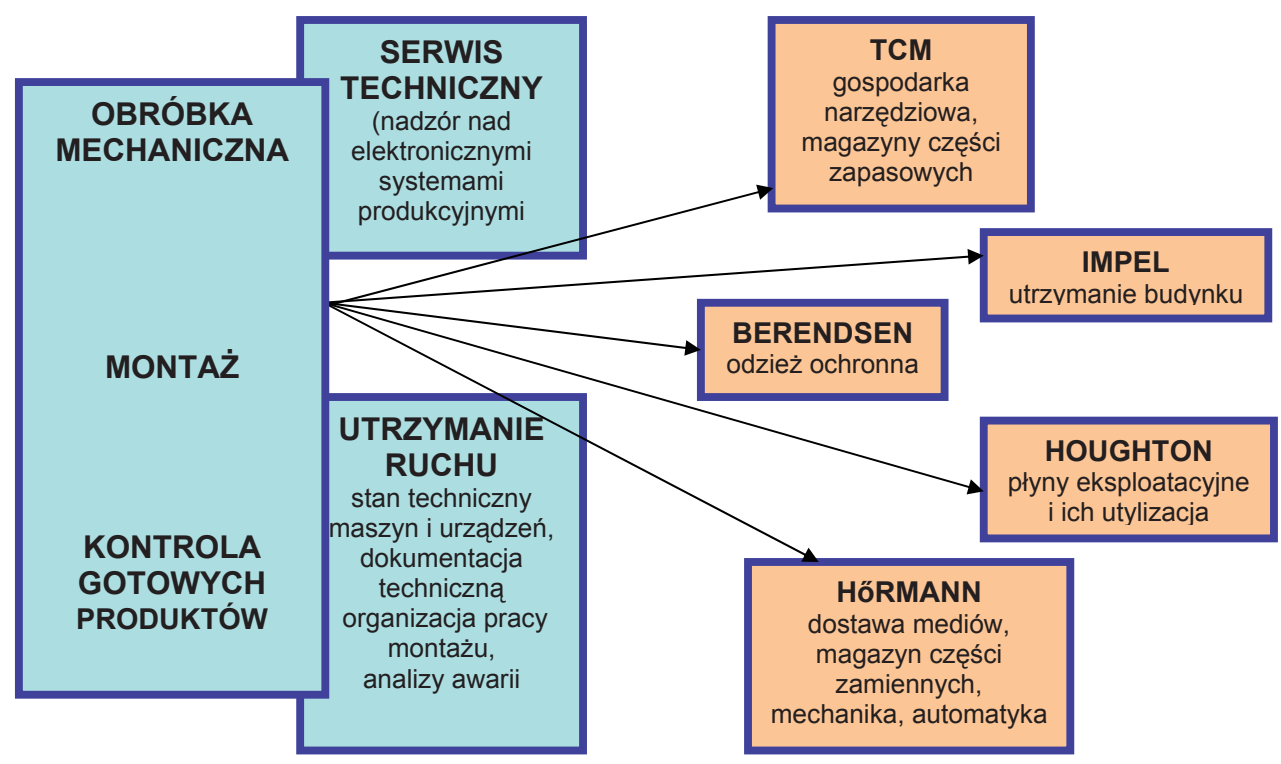

Ryc. 2. Produkcja w Volkswagen Motor Polska Sp.z o.o. i powiązania outsourcingowe

Źródło: opracowanie własne na podstawie danych z przedsiębiorstwa

\section{DOJAZDY DO PRACY JAKO ODZWIERCIEDLENIE POWIĄZAŃ PRZESTRZENNYCH}

Gwałtowne procesy industrializacji gospodarki polskiej w latach 50. i 60. XX w. zaowocowały wzrostem zainteresowania problematyką dojazdów do pracy zarówno w ujęciu przestrzennym, jak i w wymiarze społecznym (zob. Lijewski 1967; Cegielski 1977). Zainteresowanie tym zjawiskiem przyczyniło się do rozwoju ewidencji bieżącej, jak i rejestracji statystycznej dojazdów do pracy w przedsiębiorstwach państwowych oraz wielu spółdzielniach. Informacje te stawały się przydatne w trakcie realizacji funkcji paternalistycznych przez te zakłady pracy w postaci wspierania transportu publicznego lub zakładowego pracowników na obszarze intensywnych dojazdów (także na obszarach miejskich), budowy hoteli pracowniczych (np. w przypadku cukrowni). Dostępność do danych statystycznych z tego zakresu, jak i możliwości badań ankietowych wśród pracowników przyczyniły się na gruncie geografii polskiej lat 60., 70. i 80. do rozwoju badań nad dojazdami do pracy, zwłaszcza w zakresie badań ankietowych (np. kosztów społecznych takich dojazdów, motywacji dojeżdżających itp.), metod analizy przestrzenno-ekonomicznej zjawiska oraz nowych kierunków badań (np. geografii czasu).

Dojazdy do pracy na obszarach miejskich i silnie zurbanizowanych sąjednym z istotnych czynników kształtujących strukturę przestrzenną miasta i regionu miejskiego (por. Dziewoński 1976). Analizy dojazdów pracowniczych wewnątrz miast rozwinęły się przede wszystkim w polu badawczym geografii anglosaskiej, natomiast w geografii polskiej były podejmowane znacznie rzadziej (zob. Dzieciuchowicz 1979; Matykowski, Stryjakiewicz, 1989). 
Jednakże w warunkach transformacji gospodarki polskiej zostały wydatnie ograniczone możliwości badań dojazdów do pracy. Na początku lat 90. upadek lub ograniczenie działalności wielu restrukturyzowanych przedsiębiorstw doprowadziło do gwałtownego spadku dojazdów pracowniczych (m.in. grupy chłopo-robotników), a następnie do zablokowania dostępu do informacji o dojazdach pracowniczych przez przedsiębiorstwa, odwołujących się do ochrony danych osobowych, jak i dotyczących funkcjonowania samego podmiotu gospodarczego. W ostatniej dekadzie niektóre przedsiębiorstwa działające w Polsce wyrażają zgodę na badania społeczne (ankietowe) wśród swoich pracowników, ale często chcą kontrolować, a nawet sterować takim procesem badawczym.

Rejestr miejscowości zamieszkania pracowników - według oficjalnego zameldowania - uzyskano od dwóch przedsiębiorstw zagranicznych: Volkswagen Motor Polska powstałego w Starych Polkowicach (gmina Polkowice) i Swedwood Polska w Chlastawie (gmina Zbąszynek). Dane o pracownikach zagregowano w układzie gmin.

W przedsiębiorstwie Swedwood w Chlastawie było zatrudnionych 2189 osób, które zamieszkiwały w 45 gminach, a w Volkswagen Motor Polska - 1185 osób, zamieszkałych w 52 gminach. Z dalszej analizy wyłączono osoby zamieszkałe w gminach oddalonych od zakładu pracy w linii prostej ponad $100 \mathrm{~km}$, albowiem te osoby zapewne nie dojeżdżały do pracy codziennie, a wynajmowały kwatery lub pozostawały w związkach partnerskich z mieszkańcami okolicznych miejscowości. Te wykluczone z dalszej analizy osoby stanowiły jedynie $0,5 \%$ ogółu zatrudnionych i w przypadku Chlastawy mieszkały w 10 odległych gminach (Piła, Pyzdry, Słupca, Jelenia Góra, Konin, Szczecinek, Grabów nad Wartą, Kłodzko, Kartuzy, Bartoszyce), a w przypadku Polkowic - w 6 gminach (Żerków, Słubice, Racibórz, Tarnowskie Góry, Ruda Śląska, Szczawnica). Średnia odległość między gminą zamieszkania a miejscem pracy dla uwzględnionej w dalszej analizie 99,5\% pracowników dla Swedwood wyniosła 8,6 km, a dla Volkswagen Motor Polska - 15,8 km (zob. tab. 1).

Tab. 1. Charakterystyka dojazdów do pracy do Swedwood International Ltd. w Chlastawie i Volkswagen Motor Polska w Polkowicach

\begin{tabular}{|l|c|c|c|c|}
\hline \multirow{2}{*}{ Charakterystyki } & \multicolumn{2}{|c|}{$\begin{array}{c}\text { Swedwood International Ltd. } \\
\text { w Chlastawie }\end{array}$} & \multicolumn{2}{|c|}{$\begin{array}{c}\text { Volkswagen Motor Polska } \\
\text { w Polkowicach }\end{array}$} \\
\cline { 2 - 5 } & $\begin{array}{c}\text { po eliminacji } \\
\text { cały układ } \\
\text { dojazdów }\end{array}$ & $\begin{array}{c}\text { miejscowości } \\
\text { skrajnych }(0,5 \% \\
\text { dojeżdżających) }\end{array}$ & $\begin{array}{c}\text { poliminacji } \\
\text { cały układ } \\
\text { dojazdów }\end{array}$ & $\begin{array}{c}\text { miejscowości } \\
\text { skrajnych }(0,5 \% \\
\text { dojeżdżających) }\end{array}$ \\
\hline $\begin{array}{l}\text { Średnia odległość } \\
\text { dojazdów } \\
\text { (w km w linii prostej) }\end{array}$ & 9,32 & 8,56 & 16,80 & 15,77 \\
\hline $\begin{array}{l}\text { Promień dynamiczny } \\
\text { (w km) }\end{array}$ & 18,81 & 12,46 & 25,59 & 19,38 \\
\hline $\begin{array}{l}\text { Długość wektora } \\
\text { (w km) }\end{array}$ & 3,83 & 3,38 & 1,14 & 0,64 \\
\hline \begin{tabular}{l} 
Azymut wektora \\
\hline
\end{tabular} & $\begin{array}{c}90^{\circ} 00^{\prime} \\
(\mathrm{E})\end{array}$ & $\begin{array}{c}92^{\circ} 15^{\prime} \\
(\mathrm{E})\end{array}$ & $\begin{array}{c}156^{\circ} 48^{\prime} \\
(\mathrm{SSE})\end{array}$ & $\begin{array}{c}200^{\circ} 33^{\prime} \\
(\mathrm{SSW})\end{array}$ \\
\hline
\end{tabular}

Źródło: obliczenia własne 
Do charakterystyki układu przestrzennego miejsca zamieszkania dojeżdżających mogą również posłużyć miary centrograficzne (zob. Matykowski 1990). W przypadku dojeżdżających do zakładu w Chlastawie środek ciężkości analizowanego układu (dotyczącego 99,5\% zatrudnionych) znajduje się ok. 3,4 km na wschód od miejsca pracy, a dynamiczny promień (czyli standardowe odchylenie odległości) wynosi ok. 12,5 km (zob. tab. 1 i ryc. 3). Środek ciężkości dojeżdżających do zakładu Volkswagen Motor Polska jest położony bardzo blisko miejsca pracy, gdyż oddalony jest tylko o 0,6 km w kierunku SSE (zob. ryc. 4). Ta zbieżność przestrzenna miejsca pracy i środka ciężkości świadczy o dużej równowadze przestrzennej układu dojazdów, natomiast wielkość promienia dynamicznego $\mathrm{r}_{\mathrm{D}}=19,4 \mathrm{~km}$ świadczy o większym rozproszeniu dojeżdżających niż w przypadku zakładu w Chlastawie. Również analiza koncentracji dojeżdżających z koncentrycznych stref wokół zakładu pracy wskazuje, że ok. 3/4 dojeżdżających do Chlastawy zamieszkuje strefę wyznaczoną przez promień średniej odległości dojazdów, co świadczy o silnym lokalnym zakorzenienie zakładu w rynku pracy najbliższych gmin (zob. tab. 2, ryc. 3). Koncentracja dojeżdżających do zakładu Volkswagen Motor Polska jest znacznie niższa w pierwszej strefie $(43,7 \%)$, ale w dwóch najbliższych strefach zamieszkuje już ponad 90\% pracowników, co może świadczyć o subregionalnym oddziaływaniu zakładu na rynek pracy.

Tab. 2. Poziom koncentracji dojeżdżających w strefach wokół zakładów w Chlastawie i w Polkowicach

\begin{tabular}{|c|c|c|c|c|}
\hline \multirow{2}{*}{$\begin{array}{l}\text { Strefy (pierścienie } \\
\text { - wielokrotność } \\
\text { średniej odległości } \\
\text { dojazdów) }\end{array}$} & \multicolumn{2}{|c|}{$\begin{array}{l}\text { Swedwood International Ltd. } \\
\text { w Chlastawie }\end{array}$} & \multicolumn{2}{|c|}{$\begin{array}{l}\text { Volkswagen Motor Polska } \\
\text { w Polkowicach }\end{array}$} \\
\hline & $\begin{array}{c}\text { Liczba } \\
\text { dojeżdżających } \\
\text { (w osobach) }\end{array}$ & $\begin{array}{c}\text { Wartość } \\
\text { skumulowana } \\
\text { dojeżdżających } \\
(\mathrm{w} \%)\end{array}$ & $\begin{array}{c}\text { Liczba } \\
\text { dojeżdżających } \\
\text { (w osobach) }\end{array}$ & $\begin{array}{c}\text { Wartość } \\
\text { skumulowana } \\
\text { dojeżdżających } \\
\text { (w \%) }\end{array}$ \\
\hline $\mathrm{I}\left(\mathrm{do} 1 \mathrm{~d}_{\mathrm{sr}}\right)$ & 1645 & 75,5 & 515 & 43,7 \\
\hline II (od $1 d_{s r}$ do $\left.2 d_{s r}\right)$ & 322 & 90,3 & 580 & 92,9 \\
\hline III ( od $2 d_{s r}$ do $\left.3 d_{s r}\right)$ & 148 & 97,1 & 62 & 98,1 \\
\hline IV (od $3 d_{\text {sr }}$ do $\left.4 d_{s r}\right)$ & 13 & 97,7 & 4 & 98,5 \\
\hline $\mathrm{V}\left(\mathrm{od} 4 \mathrm{~d}_{\mathrm{sr}}\right.$ do $\left.5 \mathrm{~d}_{\mathrm{sr}}\right)$ & 26 & 98,9 & 9 & 99,2 \\
\hline $\mathrm{VI}\left(\right.$ od $5 \mathrm{~d}_{\mathrm{sr}}$ do $\left.6 \mathrm{~d}_{\mathrm{sr}}\right)$ & 3 & 99,0 & 9 & 100,0 \\
\hline $\begin{array}{l}\text { VII (od } 6 d_{\text {sr }} \\
\text { do } 100 \mathrm{~km})\end{array}$ & 21 & 100,0 & - & \\
\hline tącznie & 2178 & & 1179 & \\
\hline
\end{tabular}


Roman Matykowski, Anna Tobolska

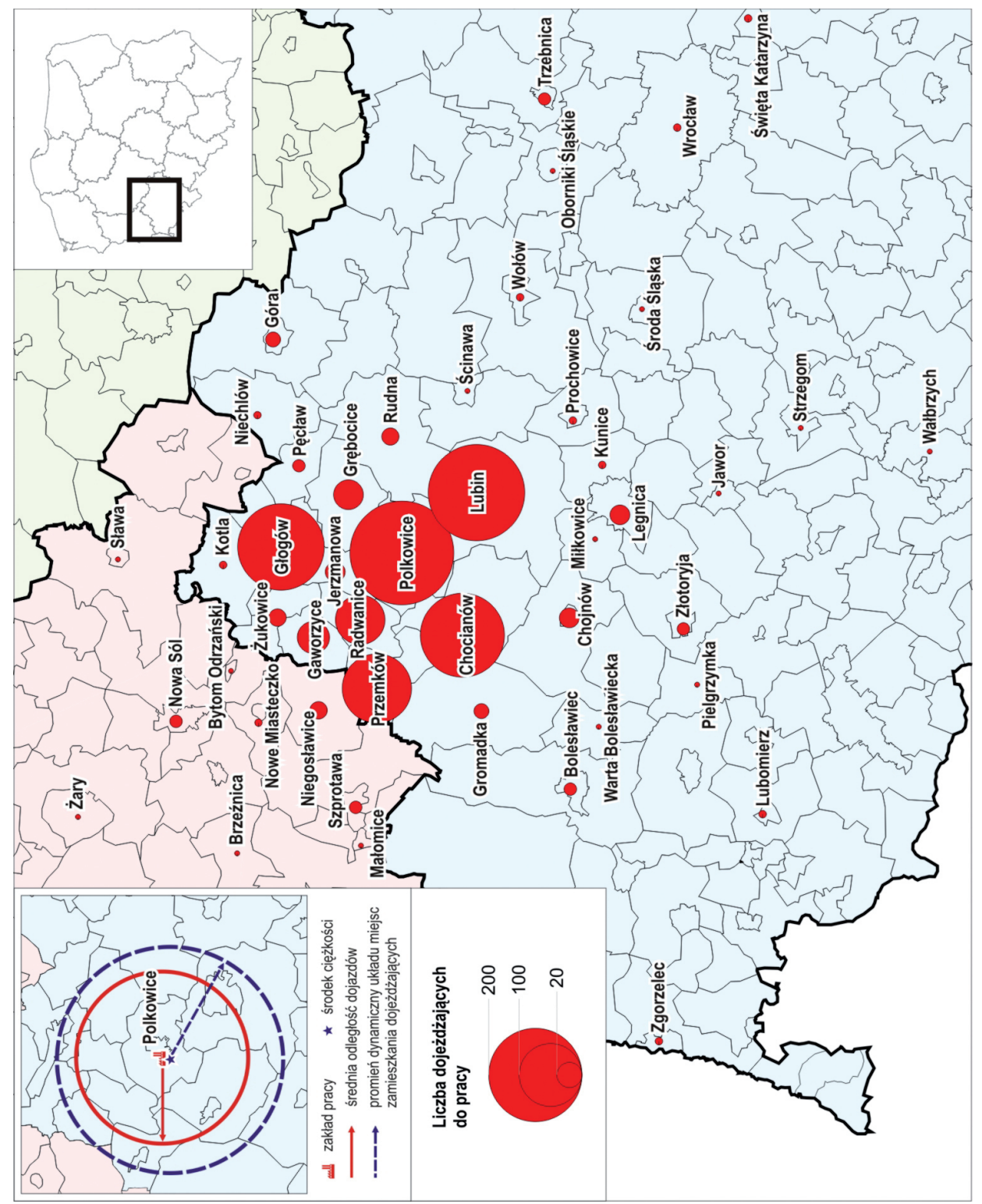

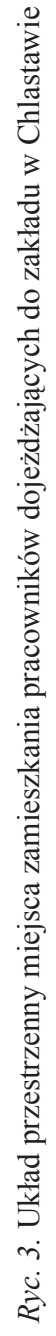




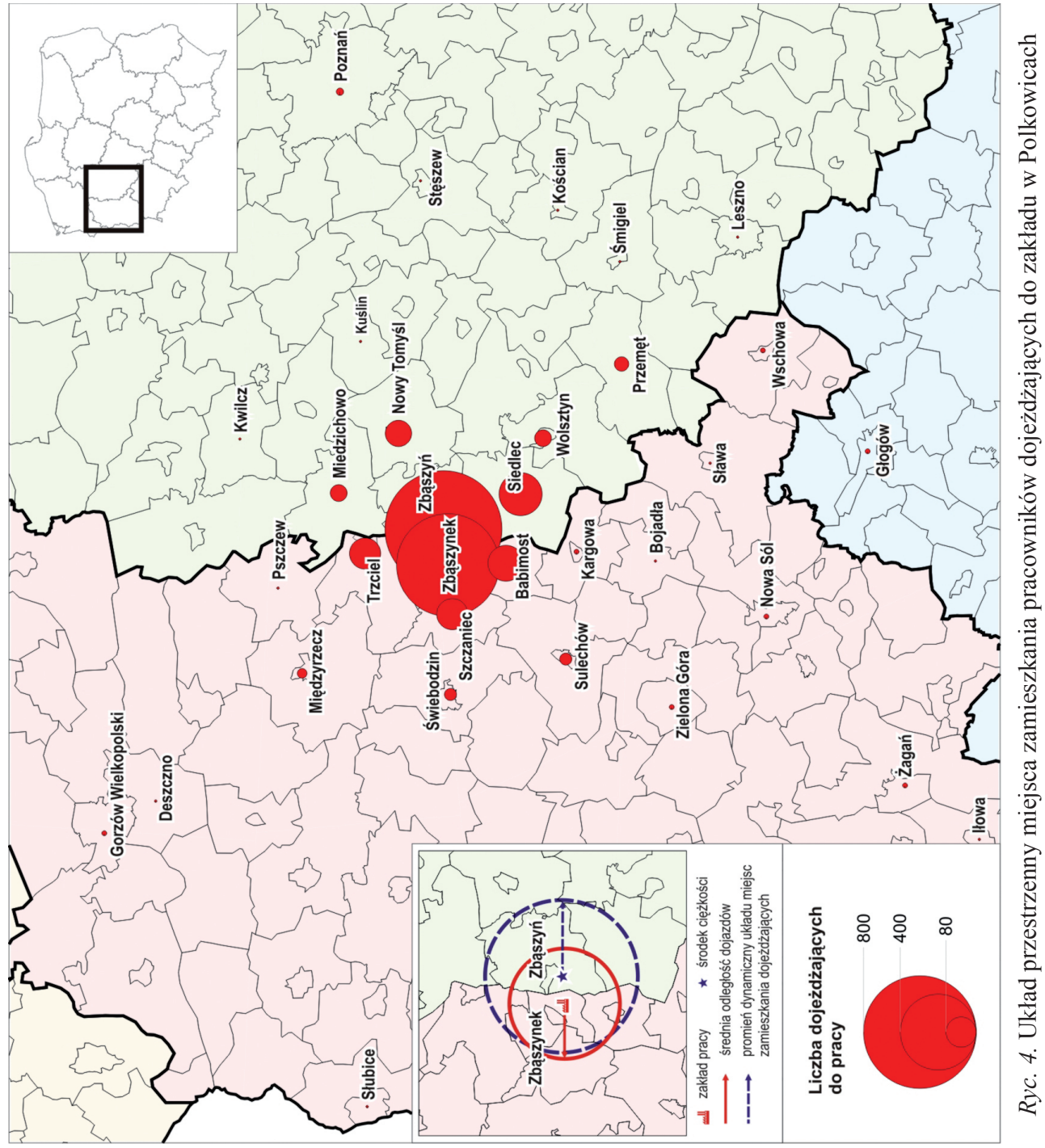




\section{Literatura}

Domański B., 1997, Geografia przedsiębiorstw - niedoceniany nurt badań w polskiej geografii ekonomicznej, [w:] Domański B., Jackowski A. red., Geografia, człowiek, gospodarka, Instytut Geografii UJ, Kraków.

Dzieciuchowicz J.Z., 1979, Rozktady przestrzenne dojazdów do pracy ludności wielkiego miasta (na przyktadzie Łodzi), Studia KPZK PAN, 66.

Dziewoński K., 1976, Wpływ migracji na systemy miejskie, „Przegląd Geograficzny”, nr 48, 2.

Gorynia M., 2007, Strategie zagranicznej ekspansji przedsiębiorstw, PWE, Warszawa.

Kutschker M., Schmid S., 2005, Internationales Management, R. Oldenbourg Verlag, MünchenWien.

Lijewski T., 1967, Dojazdy do pracy w Polsce, Studia KPZK PAN, 15.

Matykowski R., 1990, Struktura przestrzenna Gniezna i przemieszczenia jego mieszkańców, PWN, Warszawa-Poznań.

Matykowski R., Stryjakiewicz T., 1989, The Changing Organisation of Latour and the Impacts on Daily Activities, [w:] Linge G.J.R., Knaap G.A. van der ed., Labour, Environment and Industrial Change, Routledge, London-New York.

Rymarczyk J., 2004, Internacjonalizacja i globalizacja przedsiębiorstw, PWE, Warszawa.

Stonehouse G., Hamill J., Campbell D., Purdie T., 2001, Globalizacja. Strategia i zarzadzanie, Wydawnictwo FELBERG SJA, Warszawa.

Stryjakiewicz T., 1999, Adaptacja przestrzenna przemystu $w$ Polsce $w$ warunkach transformacji, Wydawnictwo Naukowe UAM, Poznań.

Śleszyński P., 2007, Gospodarcze funkcje kontrolne w przestrzeni Polski, Prace Geograficzne PAN IGiPZ, nr 213, Warszawa.

Tobolska A., 2004, Zmiany własnościowe i organizacyjno-ekonomiczne w wybranych dużych przedsiębiorstwach przemystowych Poznania w okresie transformacji, Bogucki Wydawnictwo Naukowe, Poznań.

Tobolska A., 2006a, Przestrzenne aspekty nowej organizacji i funkcjonowania przedsiębiorstw przemystowych, „Przegląd Geograficzny”, nr 78, 4.

Tobolska A., 2006b, Strategie globalne a nowe formy organizacji przedsiębiorstw transnarodowych, [w:] Zioło Z., Rachwał T. red., Rola przedsiębiorczości w podnoszeniu konkurencyjności społeczeństwa i gospodarki, Przedsiębiorczość - Edukacja, nr 2, Warszawa-Kraków.

Tobolska A., 2008, Przestrzenne aspekty ekspansji zagranicznej korporacji międzynarodowych w koncepcjach internacjonalizacji, [w:] Czyż T., Stryjakiewicz T., Churski P. red., Nowe kierunki $i$ metody $w$ analizie regionalnej. Biuletyn IGS-E iGP, UAM, Seria Rozwój Regionalny i Polityka Regionalna, nr 3, Bogucki Wydawnictwo Naukowe, Poznań.

Wdowicka M., 2005, Bezpośrednie inwestycje zagraniczne i inwestycje samorzqdowe w aglomeracji poznańskiej w okresie transformacji ustrojowej, Bogucki Wydawnictwo Naukowe. Poznań.

Zorska A., 1998, Ku globalizacji? Przemiany w korporacjach transnarodowych $i$ w gospodarce światowej, Wydawnictwo Naukowe PWN, Warszawa.

\section{Operation of 21st-century industrial plants as exemplified by Swedwood Poland and Volkswagen Motor Polska Sp. z o.o.: Analysis of journeys to work}

New foreign investments by big international corporations, whether through the purchase of privatised enterprises or greenfield-type ventures, have brought about a disintegration of old co-operation and supply networks and the emergence of new spatial links between plants and their surroundings. An analysis of those new spatial links will rest on journeys to work. As the first and most basic of the links connecting a new enterprise with its new environment and the local community, they are one of 
the best measures of the plant's range of impact and an indicator of the extent of its embeddedness in the region. The examples will be the subsidiaries of two international corporations located in Poland: of Swedwood International Ltd. at Chlastawa (Zbąszynek commune, Lubuska Land) and of the German firm, Volkswagen Motor Polska, at Polkowice (Lower Silesia).

dr Roman Matykowski

dr Anna Tobolska

Uniwersytet im. Adama Mickiewicza w Poznaniu

e-mail: mat@amu.edu.pl

e-mail: juli@amu.edu.pl 